\title{
Differential Expression of Heat Shock Proteins during Heat Stress in Tropical Tasar Silkworm, Antheraea mylitta
}

\section{Immanual Gilwax Prabhu*, Madhunita Bakshi, Manjappa, Mohammed Muzeer Baig, Prem Prakash Srivastava, Lokesh, Niranjan Kumar and Alok Sahay}

\author{
Silkworm Breeding and Genetics, Central Tasar Research and Training Institute, \\ Ranchi 835303, India \\ *Corresponding author
}

\section{A B S T R A C T}

\section{Keywords}

Heat shock protein, Chaperones,

Transcript, Thermal stress, Tasar silkworm

Article Info

Accepted:

17 November 2018

Available Online:

10 December 2018
Heat shock proteins (HSPs) usually act as molecular chaperones to prevent proteins from being denatured in response to high temperature and other extreme conditions. These are highly conserved from prokaryotes to eukaryotes. In this study, we analysed the differential expression pattern of hsp 21 and $h s p 70$ transcript during thermal stress in tropical tasar silkworm. We found expression of $h s p 21$ and $h s p 70$ were upregulated $\sim 2.5$ and 4 folds respectively in the temperature treated larvae in comparison to the control larvae. This result strongly suggests that the expression of HSP21 and HSP70 proteins are imperative for the tolerance towards the thermal stress.

\section{Introduction}

Heat shock proteins (HSPs) are a class of highly conserved proteins that are ubiquitously found in all types of organisms, from prokaryotes to eukaryotes. They are called as HSPs because of their increased expression during exposure to increased temperatures and other stresses. They are molecular chaperones, involved in many cellular functions such as protein folding, transport, maturation and degradation. Under physiological conditions, HSP are expressed in a constitutive manner, and exert fundamental house-keeping and homeostatic functions (Mallouk et al., 1999). Besides these functions HSPs also mediates the adaptive and cytoprotective responses of cells. HSPs can be divided into five families, including HSP100, HSP90, HSP70, HSP60, and sHSP (Bar-Lavan et al., 2016). This classification is mainly based on the molecular weight as well as the homologous relationship of HSPs. All of these families are conserved, except for sHSP family that is more diverse than other four $(\mathrm{Li}$ et al., 2009). sHSPs have been widely investigated in various insect species including Bombyx mori but till now no work has been done in Antheraea mylitta. Investigating the production of heat shock 
proteins by tasar silkworms in response to a heat shock might provide an insight into the cytoprotective aspect of their tolerance of thermal stress. The information obtained is also likely to provide a clue to the performance of a selection line in the field and assist in the selection of more thermo-tolerant lines.

A. mylitta, a Lepidopteran insect of the Saturniidae family produces tasar silk of commercial importance. It feeds mainly on the tender leaves of Terminalia arjuna, $T$. tomentosa, and Shorea robusta (Jolly et al., 1974; Peigler, 1993, 1994). The tasar cocoons are also reported to be the largest among all the silk-producing insects in the world (Akai, 2000). In this study, for the first time we are reporting differential expression of HSPs during heat stress in Tropical Tasar Silkworm, A. mylitta.

\section{Materials and Methods}

\section{Collection of tissues}

Fifth instar larvae of temperature treated and control group of tropical tasar silkworm were collected from rearing field of Central Tasar Research and Training Institute, Ranchi. Ten temperature treated larvae were gradually exposed to high temperature, $45^{\circ} \mathrm{C} / 4 \mathrm{~h}$ for three days and ten larvae of control group were kept at room temperature. After the third day of exposure, two individuals were collected randomly. Instantly, collected tissues were processed for RNA extraction.

\section{Extraction of RNA from silkworm tissue}

Tissue samples of $100 \mathrm{mg}$ were homogenized using liquid nitrogen. $1 \mathrm{ml}$ of TRIzol ${ }^{\mathrm{TM}}$ Reagent per $100 \mathrm{mg}$ of tissue was added and further homogenized using mortar and pestle. After proper homogenization, lysate was centrifuged at $12,000 \times \mathrm{g}$ at $4^{\circ} \mathrm{C}$ for five minutes. Clear supernatant was transferred to a new tube and incubated for $5 \mathrm{~min}$ to permit complete dissociation of the nucleoprotein complex. $0.2 \mathrm{ml}$ of Chloroform was added and incubated for $5 \mathrm{~min}$. Sample was centrifuged for $15 \mathrm{~min}$ at $12,000 \mathrm{rpm} / 4^{\circ} \mathrm{C}$. Aqueous phase containing the RNA was transferred to a new tube without disturbing the interphase or organic layer. $500 \mu 1$ of Isopropanol was added to the aqueous phase and incubated for 10 min. After incubation, sample was centrifuged at $12,000 \mathrm{rpm}$ for $10 \mathrm{~min}$ at $4^{\circ} \mathrm{C}$. Total RNA was precipitated which forms a white gel like pellet at the bottom of the tube. Supernatant was discarded and pellet was resuspended in $75 \%$ ethanol. Sample was vortexed briefly and centrifuged at $7500 \mathrm{x} \mathrm{g}$ for $5 \mathrm{~min}$ at $4^{\circ} \mathrm{C}$. Supernatant was discarded and RNA pellet was air dried for 5-10 min (Chomczynski, 1993). Final pellet was resuspended in 20-50 $\mu \mathrm{l}$ of $0.1 \mathrm{mM}$ EDTA solution and stored in $80^{\circ} \mathrm{C}$ for further reaction.

\section{Purification of extracted RNA}

Sample volume was made upto $500 \mu \mathrm{l}$ and it was transferred to a Spin Cartridge with a Collection Tube. Cartridge with sample was centrifuged at $12,000 \mathrm{rpm}$ for $1 \mathrm{~min}$ at room temperature. The flow-through was discarded and reinserted the Spin Cartridge into the same Collection Tube. Wash Buffer I of 700 $\mu \mathrm{L}$ was added to the Spin Cartridge. Centrifuge was performed at 12,000 rpm for 1 min at room temperature. Discard the flowthrough and the Collection Tube. Insert the Spin Cartridge into a new Collection Tube. Added $500 \mu \mathrm{L}$ of Wash Buffer II with ethanol to the spin cartridge and centrifuged at 12,000 rpm for $1 \mathrm{~min}$ at room temperature. Flowthrough was discarded and spin cartridge was inserted into the same collection tube. To dry the membrane, cartridge was centrifuged $12,000 \mathrm{rpm}$ for 1 minute at room temperature. Collection Tube was discarded and spin cartridge was inserted into a recovery tube. 
Added 30-100 $\mu \mathrm{L}$ of RNase-Free water to the center of the spin cartridge and incubated at room temperature for 1 minute. Spin Cartridge was centrifuged with the recovery tube for 2 minutes at $12,000 \mathrm{rpm}$ at room temperature (Chomczynski and Sacchi, 1987; Boom et al., 1990). Purified RNA was stored in $-80^{\circ} \mathrm{C}$ for further process.

\section{First strand cDNA synthesis}

RNA sample of $1 \mu \mathrm{g}(1 \mu \mathrm{l}), 2 \mu \mathrm{l}$ of $\mathrm{d}(\mathrm{T})_{23}, 1 \mu \mathrm{l}$ of $10 \mathrm{mM} \mathrm{dNTP}$ and $6 \mu \mathrm{l}$ of nuclease free water were mixed together for the preparation reaction mixture. RNA/primer was denatured for 5 minutes at $65^{\circ} \mathrm{C}$ and cooled down to ice cold condition. 10X AMV buffer of $2 \mu \mathrm{l}, 1 \mu \mathrm{l}$ of AMV RT, $0.2 \mu \mathrm{l}$ RNase inhibitor and 16.8 $\mu$ of nuclease free water were mixed together in the same vial and incubated at $42^{\circ} \mathrm{C}$ for one hour. After cDNA synthesis, enzyme was inactivated at $80^{\circ} \mathrm{C}$ for $5 \mathrm{~min}$. After reverse transcription, cDNA was stored at $-20^{\circ} \mathrm{C}$.

\section{Expression analysis of hsp21 and hsp70 genes}

Totally two pairs of HSP21 primers (Hsp21AF1, Hsp21A-R1, Hsp21A-F2 and Hsp21A-R2) and two pairs of HSP70 primers (Hsp70A-F1, Hsp70A-R1, Hsp70A-F2 and Hsp70A-R2) were designed based on the conserved regions of $h s p 21$ and $h s p 70$ gene specific transcript sequences in NCBI. The cDNA synthesized using the $1 \mu \mathrm{g}$ of total RNA from temperature treated and control group of A. mylitta were used as a PCR template. The PCR program included an initial denaturation at $94{ }^{\circ} \mathrm{C}$ for 2 min followed by 30 cycles of denaturation at $94^{\circ} \mathrm{C}$ for $30 \mathrm{~s}$, annealing at $58^{\circ} \mathrm{C}$ for $45 \mathrm{~s}$, and elongation at $72^{\circ} \mathrm{C}$ for $90 \mathrm{~s}$, followed by extension at $72{ }^{\circ} \mathrm{C}$ for $10 \mathrm{~min}$. The amplified products were electrophoresed in agarose gel. Differential expression of $h s p 21$ and hsp70transcripts between two groups were analysed based on the intensity of bands observed in agarose gel over UV transilluminator using imageJ.

\section{Results and Discussion}

\section{Tissue collection from silkworm}

The physiological response of fifth instar larvae of A. mylitta have been studied in response to thermal stress. The differential expression of transcript coding for HSP21 and HSP70 in the tissues reflects tissue specific changes in different developmental stages and in response to the imposed thermal stress. The insects living under different environmental conditions in which the intensity of dominant factors and their combination vary to different degrees causing reversible or irreversible changes in the metabolism of insects. These changes cause survival or death of an organism. In this study, fifth instar larvae were gradually exposed to $45^{\circ} \mathrm{C} / 4 \mathrm{~h}$ for three days. During the exposure, mortality and dehydration stress were not observed in the silkworm. After the third day of exposure, tissue samples were collected immediately after temperature stress and processed instantly for RNA extraction.

\section{Expression of hsp21 and hsp70 transcript after heat shock}

Total RNA was extracted using Trizol from the collective tissues after thermal stress given to fifth instar larvae and it was purified through affinity coloumn. Extracted RNA was confirmed by formaldehyde agarose gel electrophoresis through the presence of $18 \mathrm{~s}$ and 28s ribosomal RNA (Fig. 1).

The mRNA sequences of $h s p 21$ and $h s p 70$ genes were retrieved from NCBI GenBank JQ708200 and GU945198 respectively. The primers were designed for the specific quantification of $h s p 21$ and $h s p 70$ expression during heat stress (Table 1). 
Figure.1 Agarose gel electrophoresis of RNA extracted from fifth instar of A. mylitta larvae. M, marker; C, control; TT, Temperature Treated

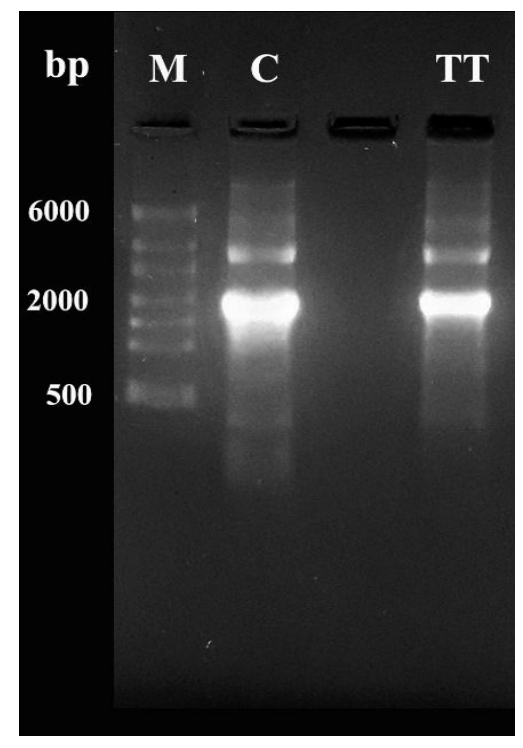

Figure.2 Agarose gel electrophoresis based quantification of heat shock protein transcript expression in temperature treated fifth instar A. mylitta larvae. (A) Expression analysis of hsp21

transcript with temperature treated (TT) and control (C) cDNA templates. (B) Expression analysis of $h s p 70$ transcript. $\mathrm{M}$ is a $1 \mathrm{~kb}$ DNA in (A) and 300bp DNA ladder in (B) used as a molecular weight standard. Graphs of relative band intensity of the amplified transcripts for each gels
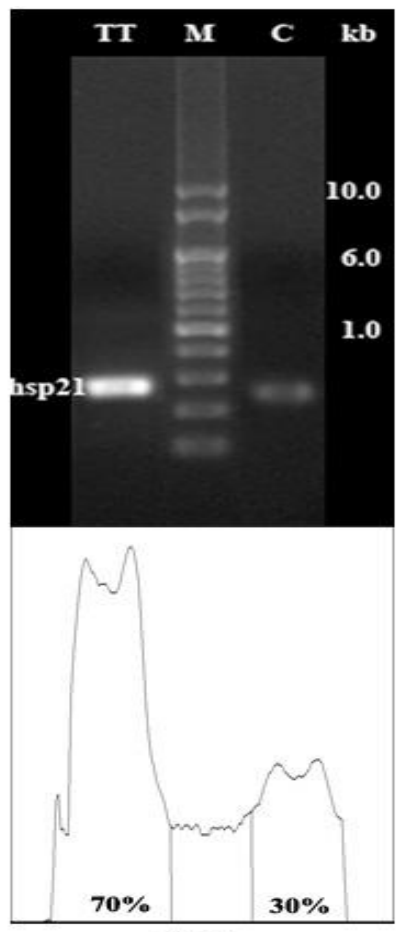

(A)
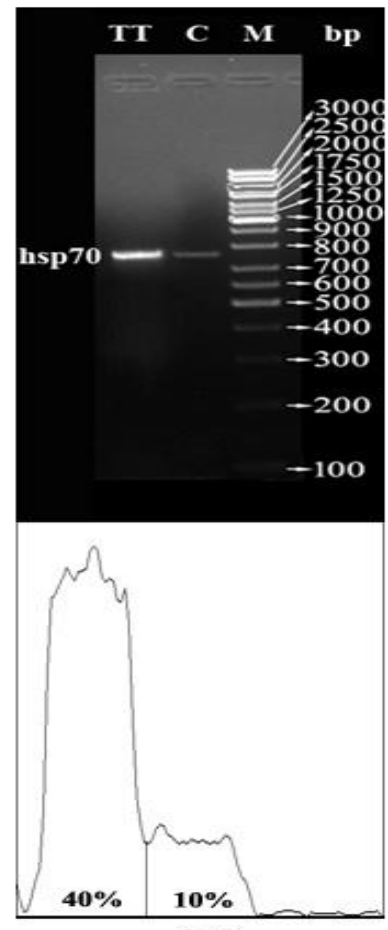

(B) 
Table.1 Description of $h s p 21$ and $h s p 70$ gene and its specific primers

\begin{tabular}{|c|c|c|c|c|c|}
\hline Gene & Description & $\begin{array}{c}\text { Gene Bank } \\
\text { Accession } \\
\text { No. }\end{array}$ & Sequence $\left(5^{\prime}-3^{\prime}\right)$ & Location & $\begin{array}{c}\text { RT-PCR } \\
\text { product size } \\
\text { (bp) }\end{array}$ \\
\hline \multirow[t]{2}{*}{ hsp21 } & \multirow[t]{2}{*}{$\begin{array}{l}\text { Heat shock } \\
\text { protein } 21 \mathrm{kDa}\end{array}$} & \multirow[t]{2}{*}{ JQ708200 } & $\begin{array}{l}\text { A-F1: CGAGGAGAAGAAAGATGAAC } \\
\text { A-R1: CTTCTCAGTTTCTTCGGTTT }\end{array}$ & $\begin{array}{l}402-421 \\
636-617\end{array}$ & 234 \\
\hline & & & $\begin{array}{l}\text { B-F2: CGTTGACACCTGAAGATTTA } \\
\text { B-R2:TTAATGCTTGATCCGACATC }\end{array}$ & $\begin{array}{l}179-198 \\
296-277\end{array}$ & 117 \\
\hline \multirow[t]{2}{*}{ Hsp70 } & \multirow[t]{2}{*}{$\begin{array}{l}\text { Heat shock } \\
\text { protein } 70 \mathrm{kDa}\end{array}$} & \multirow[t]{2}{*}{ GU945198 } & $\begin{array}{l}\text { A-F1: CAGCTATTGGAATTGATCTCGGT } \\
\text { A-R1: GGATTCATTCGCAAGTCCTTCTT }\end{array}$ & $\begin{array}{l}005-027 \\
764-742\end{array}$ & 759 \\
\hline & & & $\begin{array}{l}\text { B-F2: GGGACAGATTCACGACGTTG } \\
\text { B-R2: TCATCACTCCACCAGCTGTT }\end{array}$ & $\begin{array}{c}978-997 \\
1225-1206\end{array}$ & 247 \\
\hline
\end{tabular}


Prior to performing expression analysis of $h s p 21$ and $h s p 70$, we optimized the primers annealing temperature. Among four pairs of primers, Hsp21A-F1 and Hsp21A-R1 showed amplification for $h s p 21$ and $h s p 70$ transcript was amplified with Hsp70A-F1 and Hsp70A$\mathrm{R} 1$. The designed primers amplified the partial hsp21 and hsp70 transcript of length 230 and $760 \mathrm{bp}$. The $h s p 21$ and $h s p 70$ mRNA expression was observed in both high temperature treated and control larvae but the expression of $h s p 21$ and $h s p 70$ were found to be upregulated $\sim 2.5$ and 4 folds respectively in the temperature treated larvae (Fig. 2). This strongly suggests that the expression of HSP21 and HSP70 proteins are imperative for the tolerance towards the thermal stress.

Tolerance of $B$. mori of high temperatures is influenced by both environmental and genetic factors (Kumar et al., 2011). The better survival of a silkworm strain in the field is governed by molecular mechanisms in their cells. Therefore, the expression of $h s p 21$ gene in the tissue was up-regulated after heat shock, which indicates their products are possibly used to protect silkworms against heat shock.

In order to study the correlation between transcriptional and translational products of Hsps in B. mori, Li et al., (2012) exposed 4 day old 5th instar larvae of thermotolerant (Nistari) and thermo sensitive (Jingsong) to a heat shock of $45^{\circ} \mathrm{C}$ for $35 \mathrm{~min}$ and $41^{\circ} \mathrm{C}$ for $60 \mathrm{~min}$ and after recovering for 2 and $4 \mathrm{~h}$ the level of expression of Hsps were measured. This revealed a higher expression of Hsp19.9, Hsp20.4 and Hsp21 in the thermo sensitive breed than in the tolerant breed. As in Locusta migratoria (Wang and Kang, 2005), the phenotypic variation in the thermotolerance of silkworm is also heritable (Kato et al., 1989) and hence controlled by genetic factors. Further, Li et al., (2012) show that thermotolerance varies with breed, sex, treatment and recovery period in silkworm. Similarly, HerediaMiddleton et al., (2008) report different thermal profiles in the expression of $\mathrm{Hsp} 70$ in three different clonal lines of rainbow trout.
The expression of $h s p 21$ and $h s p 70$ were 2.5 and 4.0 folds higher in the temperature treated line than the control line. Previous reports indicate that the increase in mRNA level of Hsp70 after heat shock of 1.5 to 4 -fold is significant (Snutch et al., 1988; Requena et al., 1992; Qin et al., 2003), even though it can vary from 1- to 1000-fold (Lindquist, 1986). Hence, Hsp70 has a prominent role in heat tolerance; it is a major molecular chaperon involved in protecting organisms from extreme temperatures, by chaperoning unfolded proteins (Parsell and Lindquist, 1993). Besides its protein protecting role under stress, high levels of $H s p 70$ are known to protect intact larvae from thermal inactivation by alcohol dehydrogenase and thermal inhibition of feeding (Feder and Krebs, 1998).

Since, breeding continuously aims to produce new breeds with the desired traits, silkworm breeders' aiming to produce a new $\mathrm{breed} / \mathrm{selection}$ line tolerant of high temperatures can use $h s p 21$ and $h s p 70$ gene expression as a marker for the identification of thermo-tolerant lines.

\section{References}

Akai, H. (2000). Cocoon filament characters and post-cocoon technology. Int. J. Wild Silkmoths Silk. 5: 255-259.

Bar- Lavan, Y., Shemesh, N., and Ben- Zvi, A. (2016). Chaperone families and interactions in metazoa. Essays in Biochemistry, 60, 237.

Boom, R., C.J.A. Sol, M.M.M. Salimans, C.L. Jansen, P.M.E.W. Dillen, and J. van der Noordaa. 1990. Rapid and simple method for purification of nucleic acids. J. Clin. Microbiol. 28:495-503.

Chomczynski, P. 1993. A reagent for the singlestep simultaneous isolation of RNA, DNA and proteins from cell and tissue samples. BioTechniques 15, 532-537.

Chomczynski, P. and N. Sacchi. 1987. Singlestep method of RNA isolation by acid guanidinium thiocyanatephenolchloroform extraction. Anal. Biochem. 
162:156-159.

Heredia-Middleton P., Brunelli J., Drew R.E. and Thorgaard G.H. 2008: Heat shock protein (HSP70) RNA expression differs among rainbow trout (Oncorhynchus mykiss) clonal lines. Comp. Biochem. Physiol. (B) 149: 552-556.

Jolly, M. S., Sen, S. K., Ahsan, M. M. (1974). Tasar Culture, Ambika Publishers, Bombay.

Kato M., Nagayasu K., Ninagi O., Hara W. and Watanabe A. 1989: Studies on resistance of the silkworm, Bombyx mori L. for high temperature. In: Proceedings of the 6th International Congress of SABRAO (II). India, pp. 953-956

Kumar N., Singh H., Saha A.K. and Bindroo B.B. 2011: Development of bivoltine double hybrid of the silkworm, Bombyx mori L. tolerant to high temperature and high humidity conditions of the tropics. - Univ. J. Environ. Technol. 1: 423-434.

Li J., Moghaddam S.H.H., Du X., Zhong B.X. and Chen Y.Y. 2012: Comparative analysis on the expression of inducible HSPs in the silkworm, Bombyx mori. Mol. Biol. Rep. 39: 3915-3923.

Li, Z. W., Xue, L., Yu, Q. Y., Xiang, Z. H., Kishino, H., and Zhang, Z. (2009). The small heat shock protein (sHSP) genes in the silkworm, Bombyx mori, and comparative analysis with other insect sHSP genes. BMC Evolutionary Biology, 9: $1-14$.

Mallouk Y, Vayssier-Taussat M, Bonventre JV,
Polla BS (1999) Heat shock protein 70 and ATP as partners in cell homeostasis (Rev). Int J Mol Med 4:463-474.

Parsell D.A. and Lindquist S. 1993: The function of heat-shock proteins in stress tolerance: degradation and reactivation of damaged proteins. Annu. Rev. Genet. 27: 437-496.

Peigler, R. S. (1993). Wild silks of the world. Am. Entomol. 39: 151-161.

Peigler, R. S. (1994). Non-sericulture uses of moth cocoons in diverse cultures. Proc. Denver Museum Nat. Hist. Ser. 3(5): 120.

Qin W., Tyshenko M.G., Wu B.S., Walker V.K. and Robertson R.M. 2003: Cloning and characterization of a member of the hsp 70 gene family from Locusta migratoria, a highly thermotolerant insect. Cell Stress Chaper. 8: 144-152.

Requena J.M., Jimenez-Ruiz A. and Soto M. 1992: Regulation of hsp70 expression in Trypanosoma Cruzi by temperate and growth phase. Mol. Biochem. Parasitol. 53: 201-211.

Snutch T.P., Heschl M.F.P. and Baillie D.L. 1988: The Caenorhabditis elegans hsp70 gene family: a molecular genetic characterization. Gene 64: 241-255.

Wang X.H. and Kang 1. 2005: Differences in egg thermotolerance between tropical and temperate populations of the migratory locust Locusta migratoria (Orthoptera: Acridiidae). - J. Insect Physiol. 51: 1277-1285.

\section{How to cite this article:}

Immanual Gilwax Prabhu, Madhunita Bakshi, Manjappa, Mohammed Muzeer Baig, Prem Prakash Srivastava, Lokesh, Niranjan Kumar and Alok Sahay. 2018. Differential Expression of Heat Shock Proteins during Heat Stress in Tropical Tasar Silkworm, Antheraea mylitta. Int.J.Curr.Microbiol.App.Sci. 7(12): 2451-2457. doi: https://doi.org/10.20546/ijcmas.2018.712.278 